\title{
How to Ensure Fiscal Sustainability in Russia ${ }^{1}$
}

\author{
I. A. Sokolov ${ }^{a, *}$, S. G. Belev ${ }^{b}$, and O. V. Suchkova ${ }^{a}$ \\ ${ }^{a}$ Russian Presidential Academy of National Economy and Public Administration, Moscow, 119571 Russia \\ ${ }^{b}$ Gaidar Institute for Economic Policy, Moscow, 125993 Russia \\ *e-mail: sokolov@iep.ru \\ Received January 19, 2021; revised January 29, 2021; accepted February 17, 2021
}

\begin{abstract}
The COVID-19 pandemic and global economic crisis aggravated risks to long-term fiscal stability in Russia. The article analyzes why compliance with the fiscal rule prevents us from curbing these risks, and the way in which construction of this rule should be modified to improve its efficiency. It makes a strong case for system-based fiscal consolidation to enhance fiscal stability and presents options for optimization of spending and tax increases.
\end{abstract}

Keywords: fiscal sustainability, fiscal rule, fiscal consolidation

DOI: $10.1134 / \mathrm{S} 1075700721040158$

The pandemic and crisis of 2020 caused substantial losses in public finances. At the current stage of fighting against COVID-19 and mitigating the impact of the economic crisis, budgetary support to national economies is implemented through an increase in anticrisis government spending, discount or deferral of tax payments, and granting the state guarantees [1].

Debt financing has become a traditional primary source of financing to back direct appropriations and substitute for shortfalls in budget revenues [2-4]. In return, soft fiscal policy of this type leads to an increase in the current government deficit and a buildup of government debt [5].

In the countries combatting the crisis, government spending has been growing, although the amounts for the anticrisis measures can be allocated partially to expenditures. According to the IMF as of October 20, 2020 [1], developed countries responded to the pandemic with an increase in expenditure liabilities (obligations) and foregone revenues for tax rebates in total on average in the amount of $10 \%$ of GDP; whereas the countries with emerging markets responded to it with a volume of support of $4 \%$ of GDP. Analysis of the IMF researchers demonstrates that both the developed countries and countries with emerging market economies resorted to fiscal stimulus, despite the substantial 10 -year bond spreads relative to the 10 -year

\footnotetext{
${ }^{1}$ The article has been prepared based on report at the International Conference on Macroeconomic Analysis and Forecasting dedicated to the 85th anniversary of the birth of Academicians V.V. Ivanter and Yu.V. Eremenko and 35th anniversary of the Institute of Economic Forecasting of the Russian Academy of Sciences.
}

US treasuries as of the onset of the pandemic ${ }^{2}$. Moreover, according to Daehler et al. [6], as the pandemic propagated, these countries with emerging market economies faced an increase in the spread by at least 200 points. Under these conditions, not only implementing a countercyclical fiscal policy by means of incurring additional expenditure obligations, but also sustaining an estimated level of government expenditures during crisis can be compromised; otherwise, cutbacks in government spending or increases in taxes may create additional negative shocks to aggregate output.

The necessity to cut spending during an economic crisis may not only create an additional cyclical shock for the economy, but also can have an effect on the long-term growth rates in the case when this cutback affects the so-called productive expenditures, promoting the growth of the total factor productivity [7-11]. Retrospective analysis of the IMF researchers has shown that during a crisis it is precisely government investments [12], falling under productive expenditures [13], that are subject to the highest risks arising from the cutbacks, primarily for the developing countries.

Regretfully, Russia saw little to no notable improvements in the structure of government spending in 2010s [14]: a particular shift toward an increase in productive expenditures has been dimly felt with respect to implementation of the national priority projects since the second half of 2019, and then only due to reallocation of financing between nonproduc-

\footnotetext{
${ }^{2}$ For member states of the European Union, spreads were quoted versus that of Germany government bonds.
} 
tive expenditure items. Therefore, the crisis that broke out in 2020 held back the unfolding positive changes in the structure of the federal government spending, while putting at the forefront an objective to provide government support to business and the population and postponing the stimulus plans for economic growth through government demand.

The necessity to finance measures from three anticrisis packages and the Nationwide Economic Recovery Plan has led to an additional increase in government spending in 2020 in the amount of at least 2.1 trillion rubles. Considering also the government guarantees, postponement of repayment of the government loans issued earlier and the shortfall in revenues due to loosening the tax rules, it can be said that deterioration of the medium-term federal budget equilibrium began to loom large, while limiting substantially the fiscal policy as a tool to stimulate economic growth. Thus, Polbin et al. [15] seriously doubt the possibility to adopt any significant countercyclical fiscal policy in Russia due to a decline in government revenues, limited capabilities for borrowing, and rapid depletion of National Wellbeing Fund resources, while bypassing the current fiscal rule.

In this regard, a matter of the federal budget to recover its capacity to have a notable positive effect on economic growth primarily through an increase in investment spending depends on a successful and rapid recovery of fiscal stability, which further raises issues with respect to the budget features and procedures providing this stability.

The current fiscal rule fails to provide for fiscal stability without slowing economic development. In the global experience, the need for a fiscal rule arises from the cyclic character of economic development, the volatility of the terms of trade, and the need to sustain a certain level of government spending (in the absence of any significant realignment of state participation in the economic process). In reality, fiscal rules are designed to improve fiscal discipline and the state of government finances by introducing stringent requirements, thereby limiting the possibilities of manual control.

Four fiscal rules exist on the basis of a parameter targeted by restriction, e.g., revenues, expenditures, deficit, and debt, and multiple variations within each type. Capping government spending during a period of favorable macroeconomic and foreign trade conditions and additional debt financing of expenditures under negative shocks are common features of the rules.

Countries, however, strongly differ in the level of severity of these constraints and admissions. Thus, by the estimates of European Credit Rating Agency, the hardest fiscal rules as a response to the debt crisis were adopted in Italy and Spain in 2011 and 2012, which nevertheless are distinguished by extremely poor discipline in maintaining the discipline, whereas the weakest constraints are currently employed by the United Kingdom and Hungary.

At the same time, the "extremes" (too tight or too soft constructions of fiscal rules) are exposed to temporal instability. But the temporary character of the effect of any construction adopted in the countries with budget constraints is a rule rather than exception. There are several reasons for this. First, each rule requires an enforcement mechanism, whereas politicians are more inclined to shift the burden of solving the problems of cutbacks in spending and debt repayment off their shoulders to the next generations. In connection with this, many fiscal rules could not survive even over a single electoral cycle, e.g., in Bulgaria, Argentina, Armenia, Croatia, Hungary, Iceland, and India. Second, it may become necessary to rethink the effective budget constraints due to both the transition to new economic conditions as a consequence of fundamental shifts in the structure of economy and, correspondingly, in the tax base and as a result of cardinal reconsideration of the state participation in the development of the economy and the social sphere. Third, adherence to particular rules, e.g., limits on budget deficit levels only, not only failed to provide for fiscal stability, but also created risks of the macroeconomic shock aggravation in the case of the need to sequester expenditures in response to a temporary drop of GDP.

Macroeconomic consequences of the 2020 pandemic and introduction of quarantine measures to the budget system of the Russian Federation differ from the crises of 2008-2009 and 2014-2015 in that it is a decline in economic activity overall, rather than a drop in oil prices, that has become a factor in the decrease in budget receipts. Construction of the effective fiscal rule (just as with earlier revisions) seeks as a priority to level negative outcomes of the drop in oil prices for the budget. The spending limit of the federal budget is determined by summing three components, that is, basic $^{3}$ oil-and-gas revenues, revenues other than oiland-gas, and expenditures on the national debt service. In this context, the shortfall in oil-and-gas revenues is replaced by the resources accumulated in the National Wellbeing Fund (NWF), whereas no specific method of financing is stipulated by the rule for a shortfall in revenues other than oil-and-gas. This situation can be explained in at least two ways. First, experience of the previous crises demonstrates that it is exactly smoothing the oil price shock that becomes a determining factor for stable fiscal policy in Russia during a crisis period. Second, for the fiscal rule, the

\footnotetext{
${ }^{3}$ If actual oil price equals to cut-off price by a fiscal rule, then baseline oil-and-gas revenues equal to actual oil-and-gas revenues.
} 
focus on the oil shock can be accounted for by the fact that countries relying on export of raw material ${ }^{4}$ normally employ similar fiscal rule constructions with the accumulation of funds in an ad hoc sovereign wealth fund and the use of cut-off prices. It should be noted, however, that economies such as those of the Persian Gulf nations depend much more on commodity prices than Russia, and division into oil-and-gas and nonoil-and-gas revenues makes little sense for them. This division, though, is critical for Russia.

At the same time, crisis of 2020 highlighted the impossibility of simultaneously adhering to the current fiscal rule and avoiding procyclical fiscal policy under current macroeconomic conditions. As a result, adherence to the fiscal rule was suspended for 2021 in the hope of its further use beginning in 2022. However, in our view, the current design of the fiscal rule is destined for changes due to the following circumstances.

The oil benchmark price has been rising slowly but surely at $2 \%$ annually and by 2030 will amount to 51.7 US dollars per barrel, that is, might be steadily higher than the projected (real) price, thus inducing the ongoing use of NWF funds, whose levels of liquidity are miniscule.

Stable reduction of the oil-and-gas receipts accompanied by a deceleration of the dynamics of the oiland-gas revenues, which are likewise procyclical, will symmetrically reduce NWF spending limits in that as early as 2030 the latter will not go beyond $15 \%$ of the GDP, which corresponds to the federal government spending level of the early 2000s.

In a short time, spending limits might deflate to include recurring operational federal expenditures only, while all budgetary investments will be financed from debt loans. This will create a highly unsteadystate model of stimulating economic growth at the expense of the budget, that is, investments will depend on the debt situation. Apparently, the effective fiscal rule can successfully function only under favorable macroeconomic conditions, i.e., relatively high oil price and nonnegative rates of the long-term economic growth, and, thus, is too short-lived.

Approaches to changing the fiscal rule. A number of conditions should be met when reviewing approaches to modification of the effective fiscal rule [16], specifically, elimination of procyclicity of government spending and provision for transparency of the procedures, including establishment of targeted values of the parameters utilized in the fiscal rule.

According to the study [17], commonly procyclicity of fiscal policy more strongly manifests itself during

\footnotetext{
${ }^{4}$ High level of dependency of federal revenues on energy prices holds true at $32 \%$ of all budget revenues in the 2020 prices.
}

the years of economic upturn rather than the recession period. Transparency of expenditure budgeting, however, is critical particularly during a recession to avoid a rise of interest rates on government loans.

The global experience of using fiscal rules based on debt and deficit ceilings, has shown their inefficiency in eliminating the procyclical nature of the fiscal poli$\mathrm{cy}^{5}$, therefore, their application is impractical. Considering that in the recent decades, negative macroeconomic shocks in Russia were primarily associated with a drop in oil prices, the practice of setting up sovereign reserves through the accumulation of natural resource rent should not be abandoned. At the same time, in our view, a new version of the fiscal rule must make a room for shocks other than a change in oil prices and be built upon the understanding of what other (than oil-and-gas) revenues are vulnerable to shocks from oil prices. These two factors are reflected in the fiscal rule of, e.g., Chile.

As to a shortfall in oil-and-gas revenues under negative macroeconomic shocks, the principle of a cyclically adjusted budget is followed by Switzerland, Germany, the United Kingdom, and other countries along with Chile. The principle presumes that the state expands utilization of loans as GDP contracts and pays them off once the economy recovers. This involves an assessment of structural revenues. Based on specialized statistical techniques, e.g., the Hodrick-Prescott filter, GDP is divided into the structural and cyclical components [18] followed by an estimation of the amounts of structural revenues [19]. Experience of using the fiscal rules oriented toward cyclical equilibrium has shown that the countries applying them managed to reduce considerably the level of their national debt. Thus, these countries succeeded in improving fiscal stability.

It should be kept in mind, however, that similar to other rules of the state economic policy, fiscal rules cannot make provisions for each possible scenario of the development of macroeconomic situation. As these situations arise, departure from fiscal rules might be a good idea when compliance with them triggers either the aggravation of economic conditions or impedes long-term economic growth. Therefore, as a flexibility component, the fiscal rule must provide for one-off factors or, in other words, an escape clause, which is present in the system of fiscal constraints in a number of countries, such as Germany, the United Kingdom, Slovakia, Switzerland, Brazil, etc. This rule presumes that expenditure ceiling may be raised beyond the limit stipulated by the fiscal rule given a

\footnotetext{
${ }^{5}$ The norm of deficit-free federal budget was removed from the Budgetary Code of the Russian Federation during crisis of 2008-2009, in view of these circumstances.
} 
very sharp change in economic conditions, natural disasters, etc. ${ }^{6}$ The ongoing crisis has demonstrated that the introduction of a clause of this kind is a relevant practice for Russia as well.

Therefore, a new version of the fiscal rule capable of providing for fiscal stability must entail the following.

1. The spending limit of the federal budget will be the sum of three addends: baseline oil-and-gas ${ }^{7}$ revenues, structural revenues other than the oil-and-gas, and expenditures on the national debt service.

2. Similar to the previous version, benchmark oiland-gas revenues should be determined based on the cut-off price; therewith, it is best to stick to a conservative approach in estimating its value, that is, 40 U.S. dollars per barrel in the 2017 prices. The rigidity can be enhanced by a transition from the cut-off price in dollars to rubles when the benchmark price in dollars is converted to rubles at the exchange rate corresponding to the cut-off price.

3. Structural oil-and-gas revenues have to be estimated based on the separation of structural and market components while it is preferable to commit to a more transparent estimation technique. The Swiss experience proved to be more successful than the Chilean not least because of this fact.

4. It is essential to state explicitly a contingency clause in a rule of this kind; the fact of the onset of these "unforeseen circumstances" must be admitted based on a "strict" enough decision-making mechanism, e.g., a supermajority in parliament, and a transparent procedure for establishing a ceiling on resources that can be applied toward implementation of anticrisis measures.

5. The National Wellbeing Fund must function exclusively as a "rainy-day fund" in the event of bad commodity price situation. At this, it is advisable to enhance the NWF at the time when commodity prices exceed the cut-off price, while the Fund must have "anticrisis clauses," which would allow channeling its reserves toward financing of the program on anticrisis measures without the restriction on the amounts at the discretion of the Government of the Russian Federation.

Implementing this kind of the rule will imply a transition period of a minimum of two or three years in view of the need for a significant budget consolidation. What happens is that the underlying problems of

\footnotetext{
${ }^{6}$ For example, in Switzerland, circumstances must be deemed as such by both chambers of the Federal Assembly.

${ }^{7}$ As a share of mineral mining taxes in federal revenues increases, it is advisable to look into the possibility of extending the cut-off price determination practice to individual minerals (the aforementioned Chilean experience shows it is not unrealistic). Then, analytical division into the oil-and-gas and other than oil-andgas revenues could be reasonably substituted by commodity and noncommodity tax receipts.
}

fiscal imbalance cannot be solved even providing a change in the fiscal rule and enforcing strict compliance with it. Data shows [20] that issues at hand are two factors, such as, a steady decline in oil-and-gas revenues and noncompletion of Pension Reform, which ensures a balanced budget for the Pension Fund of the Russian Federation. Therefore, long-term fiscal stability directly depends on responses to these challenges.

Introduction of system-based budget consolidation as a response to the challenges of long-term fiscal sustainability. Budget consolidation is understood as reduction in budget deficit via either spending cuts or increases in taxes [21]. Internationally, particular countries resorted to fiscal consolidation more than once. The most recent large-scale consolidation efforts were launched as a result of the global crisis of 2008-2009 [22]. The drop in revenues occasionally accompanied by an increase in expenditure commitments due to implementation of the anticrisis economic support program fuels borrowing, thus dictating the need for fiscal consolidation. It should be noted, however, that to avoid deeper recession, countries made the best efforts to delay fiscal consolidation, considering the negative impact of the latter on GDP. Opportunities for this arose from the extent of each country's access to debt financing [23]. Particular countries, such as Estonia and Hungary, had to start as early as in 2009; whereas the majority of the OECD countries launched it in 2011; while other countries did it even later, e.g., Germany, United States, and Japan. The consolidation was somewhat mitigated as budget receipts grew even more rapidly with the economic growth, while part of the reduction in expenditures occurred automatically due to the temporary nature of the anticrisis measures.

Nevertheless, consolidation necessitated changes, which were induced by increases in the tax burden and (or) contraction of expenditure commitments. Assessments of the effects of fiscal consolidation revealed the following [24-26]:

(1) Slowdown in the growth rates occurs regardless of consolidation type.

(2) Spending cuts reduced the GDP to a lesser degree than a tax hike.

(3) Gradual prolonged deficit reduction triggered a less significant drop in GDP than the one-time reduction.

Russia joined other countries in a chain of fiscal consolidations, notwithstanding that the process was smoothed down as the economic recovery was unfolding against a general revival of the world economy, while the associated rise in oil prices led to an increase in budget receipts. Specifically, the most recent sequestration of expenditures was applied in 2015 when all conditionally unprotected expenditure items 


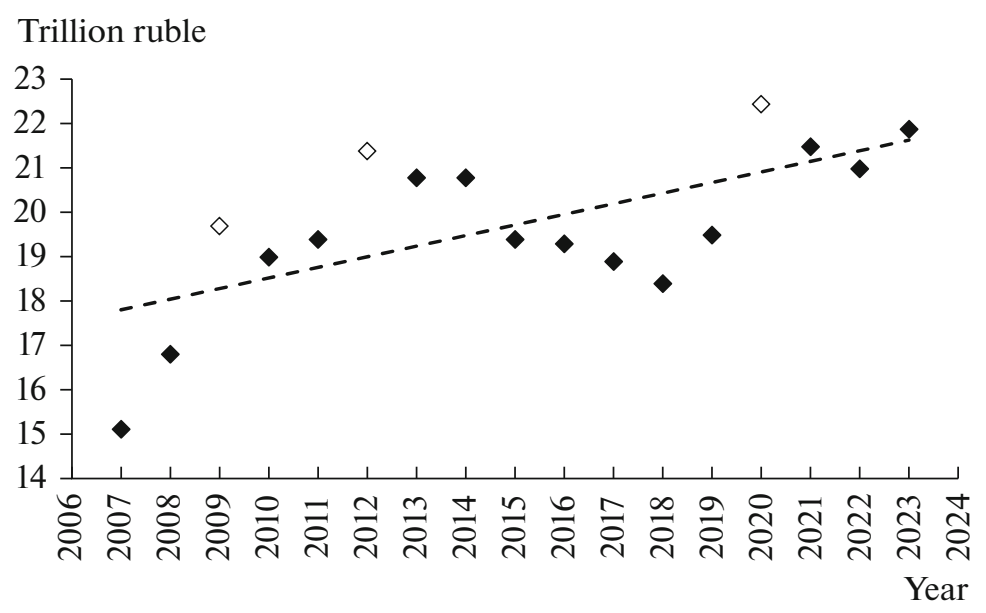

Fig. 1. Dynamics of government spending, in 2021 prices.

of the budget were capped at $15 \%$ of the annual total level and at a stage of federal budgeting in 2016 when ceilings were slashed in all the unprotected programs and nonprogram expenditures by $10 \%$.

Under front-loaded sequestration, a problem lies not so much in a lack of statutory procedures for optimizing government spending, as well as procedures for recognizing them as inefficient, but rather a lack of perspective on medium-term priorities with budget allocations. Application of this approach commonly resulted in cuts to productive expenditures (primarily, of a capital nature). Thus, in 2016 labor costs increased by $5.4 \%$, while expenditure on financing the investments in capital construction declined by $16.1 \%$ with the planned $10 \%$ sequester with respect to unprotected items on an incurred basis.

"Selective" consolidation involving the reduction of particular (selected) allocations, for the most part also failed to yield an appreciable fiscal effect. isteispecifically, in 2014 the number of supported FTPs (Federal Target Programs) was reduced from 49 to 46, while the total planned spending contracted from 1025.5 in 2013 to 937.2 billion rubles in 2014 . The effect of the selective consolidation, however, was temporary in that the cuts to some items were substituted by an increase in the amount of financing to others or compensated for in the subsequent years.

The figure 1 is more illustrative in terms of the effectiveness of fiscal consolidation in Russia. Each spike $(\diamond)$ in federal expenditures $(2009,2012$, and 2020) was followed by their optimization, but still the uptrend in expenditures did not face breakpoints.

Undoubtedly, one might speak of the necessity for adopting a stringent fiscal policy immediately after surmounting the current economic crisis. The practice of the recent decade, however, casts doubt on the effectiveness of all types of fiscal consolidation applied in Russia, namely, suspension of construction projects and investment spending on purchases (rightward shift), selective optimization, front-loaded sequester, and absence of indexation. All of these speak to shallow spending cuts; besides, the optimization primarily focused on investment expenditures (purchases of investment goods, construction, etc.) or expenditures stimulating growth, such as subsidies, equity investment, etc.; therefore, their subsequent reinstatement was amply justified.

When conducting spending optimization in the future, it is critically important to avoid cuts to productive-type expenditures in real terms compared to the level attained in 2020, which is further complicated by the factor of low flexibility of the federal budget structure. The point is that the major spending structure rigidity is created through the so-called semifixed (protected) expenditures. We estimate that they predetermine federal spending in the amount of up to 14.5 trillion rubles under the conditions of 2021 and consist of expenditures on wages of civil servants, military and equal-status personnel, and the staff of public institutions; public-legal obligations; transfers to extrabudgetary funds; equalization transfers and to subventions; grants to fulfill state assignments on public service delivery by institutions funded from the state budget and autonomous institutions; compensation subsidies to juridical persons; fulfillment of international obligations; expenditures on the national debt service; etc. All of the expenditures largely arise from a significant share of direct participation of the state in the economy, on the one hand, and traditionally high demand for public goods, on the other. Therefore, it appears difficult to reduce semifixed expenditures appreciably in the foreseeable future without sharply reducing the state participation in the economy and social sphere, as well as reconsidering social commit- 
ments, which is inevitably associated with increased social tension in society.

Below, we propose tactics to conduct fiscal consolidation overall to mitigate its negative impact on economic growth.

(1) Spending should be cut following the onset of economic recovery.

Therefore, fiscal consolidation might be justifiably launched in Russia in 2022, while in 2021 it is possible to reduce spending by the phasing out of anticrisis measures.

(2) It is advisable to cut spending systematically without resorting to a one-time sequester. Specifically, we propose to use the "deferred payment" approach for the investment-type expenditures (a rightward shift concerning new construction and investment purchases), as well as selective consolidation for nonpriority spending and, primarily, the stimulating subsidies to branches that were not classified by the Government of the Russian Federation as the hardest-hit by the crisis.

(3) The amount of possible budget savings should be determined from negative difference between predicted and structural levels of oil-and-gas revenues to avoid additional borrowings.

Given the lack of a privatization initiative on the part of the state and the unwillingness to reconsider social commitments, we estimate that the real effect from optimization would barely exceed 500 billion rubles of net saving, i.e., without the subsequent reinstatement of the reduced spending as macroeconomic conditions improve. Therefore, in circumstances where there is a tendency for a steady decline in oiland-gas receipts and a pronounced rigidity of the federal spending structure remaining, this prevents appreciably (at least by $2 \%$ of the GDP) cutting the latter out of expenditures other than the productive, and unwittingly turns the spotlight on tax-based fiscal consolidation.

Capacity estimation of increase in tax receipts. According to studies [24, 26], an increase in taxes as an option in fiscal consolidation comes laden with higher risks to the economic recovery than the option of government spending cuts. At the same time, it should be noted that these studies failed to consider an option of tax burden expansion, such as taxation of natural resource rent and pollution of the environment. Natural rent taxation is characterized by less adverse effects on economic activity [27-29], while environmental taxation creates the so-called double dividend due to not only generating additional receipts to budget, but also contributing to the reduction of environmental damage [30, 31]. Our estimate is that moving forward with environmental fees might generate up to 200 bil- lion rubles annually. A proposal of the Russian Ministry of Finance ${ }^{8}$, which has been implemented starting 2021, to raise the tax burden on commercial mineral mining likewise appears to be a prudent measure. According to the World Bank estimates, a commercial mineral mining rent in Russia varies within a range of $1 \%$ of the GDP, which accounts for approximately $10 \%$ of the oil rent level. Thus, with the same level of rent extraction, this might generate an additional 500 billion rubles annually. Besides, according to estimates by Kaukin and Miller [32], in the oil and gas sector it is possible to adjust the tax maneuver intended to abolish export oil duties in exchange for an increase in the natural resource taxation rate, which will additionally generate approximately 400 billion rubles annually. And while the trick with taxation of natural resource rent extraction is fraught with the budget becoming even more vulnerable to changes in trading terms and foreign market conditions, the adjusted fiscal rule together with the NWF are capable of neutralizing the fiscal risks of a drop in commodity prices most successfully.

Finally, if these measures prove to be insufficient for financing the surging spending level, a consumption tax has certain fiscal capacities. First, taxation of consumption applies to each household, whereas taxation of income concerns only those who have income, that is, a tax rate increase will not be that high with the broader tax base [33]. Second, the less are the opportunities for evasion in consumption compared to income, the stronger is the weight of the preceding argument in favor of taxation of consumption [34]. Data shows [35] that over the 2010s in Russia, the value-added tax collection rate grew not least due to the automation of tax administration. This suggests favoring the option of an increased tax burden through improvement of the value-added tax collection rates due to tax harmonization within the EAEU, reduction of the threshold (which manyfold exceeds the foreign analogs) for the admission of small business to the USN (Simplified Tax System); and reduction of the list of goods with preferential value-added tax rate, taxation of which generates a small equalizing effect of welfare [36]. We estimate that the fiscal effect from an increase in the VAT rate up to $22 \%$ may amount to 1.5 trillion rubles with the implementation of the foregoing measures, serving to improve its collection rate.

Conclusions. To ensure long-term fiscal stability requires finding solutions to fundamental challenges, such as falling oil-and-gas revenues, the rigid structure of budget expenditures, and an unbalanced pension system, rather than tuning (refining) a system of response to short-lived macroeconomic shocks. At the

\footnotetext{
8 "Main Lines of Fiscal, Taxation, and Custom Tariff Policies for 2021 and Planning Period of 2022 and 2023” (October 2020).
} 
same time, the presence of time-flexible and rigidly observed fiscal rules has the capacity to improve notably the quality of fiscal policy as a tool for management of the economy by the state, while eliminating the problem of uncontrolled growth of the debt burden.

In our opinion, sustaining long-term fiscal stability implies implementing both optimization of the nonproductive expenditures portion and an increase in the tax burden. In these settings, the least adverse options of economic activity will include an increase in environmental fees and natural resource rent and, in the context of Russia, strengthening the mineral mining tax burden and adjusting a tax maneuver in the oiland-gas sector. In the case of inadequacy of these tax measures, it is advisable to resort to an increase in the VAT rate along with improvement of its administration. Moreover, it is pivotal to make the decision on tightening the tax treatment well in advance (three or four years) before its implementation for all the participants involved to be able to adjust their business models and market behavior.

\section{CONFLICT OF INTERESTS}

The authors declare that they have no conflict of interest.

\section{REFERENCES}

1. Fiscal Monitor Database of Country Fiscal Measures in Response to the COVID-19 Pandemic. https://www.imf.org/en/Topics/imf-and-covid19/Fiscal-PoliciesDatabase-in-Response-to-COVID-19.

2. E. lzetzki, E. G. Mendoza, and C. A. Végh, "How big (small?) are fiscal multipliers?," J. Monetary Econ. 60, 239-254 (2013).

https://doi.org/10.1016/j.jmoneco.2012.10.011

3. V. Ramey, "Can government purchases stimulate the economy?,” J. Econ. Liter. 49 (3), 673-685 (2011).

4. A. Auerbach and Y. Gorodnichenko, "Measuring the output responses to fiscal policy," Am. Econ. J.: Econ. Policy 4 (2), 1-27 (2012).

5. W. Corden, "The theory of the fiscal stimulus: How will a debt-financed stimulus affect the future?," Rev. Econ. Policy 26 (1), 38-47 (2010). https://doi.org/10.1093/oxrep/grq001

6. T. Daehler, J. Aizenman, and Y. Jinjarak, Emerging Markets Sovereign Spreads and Country-Specific Fundamentals During COVID-19. NBER Working Paper No. 27903 (2020). https://www.nber.org/system/files/ working_papers/w27903/w27903.pdf. Accessed December 16, 2020.

7. R. J. Barro, "Government spending in a simple model of endogenous growth," J. Polit. Econ. 98 (5), 103-126 (1990).

8. D. Aschauer, "Is public expenditure productive?," J. Monetary Econ. 23 (2), 177-200 (1989).

9. W. Easterly and S. Rebelo, "Fiscal policy and economic growth,” J. Monetary Econ. 32 (3), 417-458 (1993).
10. G. Idrisov and S. Sinel'nikov-Murylev, "Budgetary policy and economic growth," Vopr. Ekon., No. 8, 3559 (2013).

https://doi.org/10.32609/0042-8736-2013-8-35-59

11. A. Kudrin and A. Knobel', "Fiscal policy as a source of economic growth," Vopr. Ekon., No. 10, 5-26 (2017). https://doi.org/10.32609/0042-8736-2017-10-5-26

12. IMF. Fiscal Monitor. April 2020. https://www.imf.org/en/Publications/FM/Issues/2020/ 04/06/fiscal-monitor-april-2020. Accessed January 6, 2021.

13. P. Bom and J. Ligthart, "What have we learned from three decades of research on the productivity of public capital?," J. Econ. Surv. 28 (5), 889-916 (2014). https://doi.org/10.1111/joes.12037

14. A. Kudrin and I. Sokolov, "Budgetary maneuver and restructuring of the Russian economy," Vopr. Ekon., No. 9, 5-27 (2017). https://doi.org/10.32609/0042-8736-2017-9-5-27

15. A. V. Polbin, S. G. Sinel'nikov-Murylev, and P. V. Trunin, "Economic crisis of 2020: Causes and measures to overcome it and further development of Russia," Vopr. Ekon., No. 6, 5-21 (2020). https://doi.org/10.32609/0042-8736-2020-6-5-21

16. E. T. Gurvich and I. A. Sokolov, "Fiscal rules: Excessive constraint or essential tool for fiscal resilience?," Vopr. Ekon., No. 4, 5-29 (2016). https://doi.org/10.32609/0042-8736-2016-4-5-29

17. F. Balassone and M. S. Kumar, "Cyclicality of fiscal policy," in Promoting Fiscal Discipline, Ed. by T. TerMinassian and M. S. Kumar (Int. Monetary Fund, Washington, DC, 2007), pp. 19-35.

18. S. Drobyshevsky, G. Idrisov, A. Kaukin, P. Pavlov, and S. Sinelnikov-Murylev, "Decomposition of growth rates for the Russian economy,” Russ. J. Econom. 4 (4), 305-327 (2018). https://doi.org/10.3897/j.ruje.4.33617

19. A. L. Kudrin and I. A. Sokolov, "Fiscal rules as an instrument of balanced fiscal policy," Vopr. Ekon., No. 11, 5-32 (2017). https://doi.org/10.32609/0042-8736-2017-11-5-32

20. E. L. Goryunov, L. Kotlikoff, and S. G. Sinel'nikovMurylev, "Budgetary gap: An estimate for Russia," Vopr. Ekon., No. 7, 5-25 (2015). https://doi.org/10.32609/0042-8736-2015-7-5-25

21. A. Fatás and L. H. Summers, "The permanent effects of fiscal consolidations," J. Int. Econ. 112, 238-250 (2018). https://doi.org/10.1016/j.jinteco.2017.11.007

22. H. Bi, E. M. Leeper, and C. Leith, "Uncertain fiscal consolidations," Econ. J., R. Econ. Soc. 10, 31-63 (2013).

23. "Fiscal consolidation: Targets, plans and measures," OECD J. Budgeting 11 (2), 15-67 (2011). https://doi.org/10.1787/budget-11-5kg869h4w5f6

24. A. Alesina, C. Favero, and F. Giavazzi, "The output effect of fiscal consolidation plans," J. Int. Econ. 96, S19-S42 (2015). https://doi.org/10.1016/j.jinteco.2014.11.003

25. A. Alesina, C. Favero, and F. Giavazzi, "Effects of austerity: Expenditure- and tax-based approaches," J. 
Econ. Perspect. 33 (2), 141-162 (2019).

https://doi.org/10.1257/jep.33.2.141

26. A. Alesina and S. Ardagna, "Large changes in fiscal policy: Taxes versus spending," Tax Policy Econ. 24 (1), 35-68 (2010). https://doi.org/10.2139/ssrn.1502862

27. C. L. Ballard and D. Fullerton, "Distortionary taxes and the provision of public good," J. Econ. Perspect. 6 (3), 117-131 (1992). https://doi.org/10.1257/jep.6.3.117

28. G. Schwerhoff, O. Edenhofer, and M. Fleurbaey, "Taxation of economic rents," J. Econ. Surv. 34 (2), 398-423 (2020). https://doi.org/10.1111/joes. 12340

29. D. Lund, "Rent taxation for nonrenewable resources," Annu. Rev. Resour. Econ. 1, 287-308 (2009). https://doi.org/10.1146/annurev.resource.050708.144216

30. L. H. Goulder, "Environmental taxation and the double dividend: A reader's guide," Int. Tax Public Finance 2, 157-183 (1995). https://doi.org/10.1007/BF00877495

31. D. Fullerton, A. Leicester, and S. Smith, Environmental Taxes (Oxford Univ. Press, Oxford, 2010).
32. A. S. Kaukin and E. M. Miller, "Tax maneuver in the oil industry: Intermediate results and risks of further implementation," Vopr. Ekon., No. 10, 28-43 (2020). https://doi.org/10.32609/0042-8736-2020-10-28-43

33. R. Boadway, M. Marchand, and P. Pestieau, "Towards a theory of the direct-indirect tax mix," J. Public Econ. 55 (1), 71-88 (1994).

34. W. F. Richter and R. W. Boadway, "Trading off tax distortion and tax evasion," J. Public Econ. Theory, No. 7, 361-381 (2005).

35. E. A. Leonov and I. A. Sokolov, "Collectability of value added tax: Revealing new determinants," Ekon. Polit. 15 (6), 42-65 (2020).

https://doi.org/10.18288/1994-5124-2020-6-42-65

36. S. G. Belev and K. V. Vekerle, "Analysis of the efficiency of tax expenditures in Russia on the example of property tax deduction and preferential VAT rate," Ars. Adm. 10 (4), 610-630 (2018). https://doi.org/10.17072/2218-9173-2018-4-610-630

Translated by E. Kuznetsova 